\title{
PRÁTICAS ECONÔMICAS E FORMAS ORDINÁRIAS DE CÁLCULO*
}

Florence Weber

O interesse pelos raciocínios nativos é uma das principais características do método etnográfico: compreender o que fazem as pessoas observadas é, também, compreender o que elas crêem fazer, mesmo se esta primeira etapa não é suficiente. Essa exigência etnográfica (restituir as categorias do pensamento nativo), ainda que vastamente resultado do interesse dos durkheimianos pela língua e pelas classificações ${ }^{1}$, recorta a definição weberiana de uma sociologia que se interessa ao mesmo tempo pelo que pensam os atores, pelo que eles fazem e pelo que eles são.

É seguramente ilusório acreditar que esses raciocínios nativos ${ }^{2}$ são sempre explícitos, sempre formulados em um discurso coerente, sempre conscientes. Uma parte expressiva de nossos raciocínios são automáticos e infraconscientes, e encarna-se mais em objetos e em procedimentos do que em exposições. Isto é tanto mais verdadeiro quando nos aproximamos da vida cotidiana, da administração ordinária dos problemas de todos os dias, no universo profissional como no universo doméstico, onde vigora o que Pierre Bourdieu chamou de "o senso prático". Esses automatismos nos são, aliás, necessários para efetuar o grande número de tarefas, indissociavelmente materiais e intelectuais, que nos esperam a cada dia. Alguns atos, ao contrário, raros e solenes, são objeto de longas deliberações. Mesmo então, é preciso confrontar os princípios de justificação desses atos com as ferramentas cognitivas que enquadram, a despeito mesmo de seu autor, o raciocínio empregado.

Seria portanto absurdo pensar que, ao despertar, cada um de nós efetua um cálculo explícito para o conjunto das microdecisões que tomaremos ao longo de todo o dia. Seria completamente absurdo também crer que os comportamentos humanos se inscrevem todos nos mesmos quadros de pensamento e de ação - restituídos, mais ou menos conscientemente, pelo observador com suas capacidades limitadas de imaginação. Os economistas evidenciam etnocentrismo ou anacronismo quando utilizam seu mo- 
delo de maximização da utilidade sob limites sem dispor dos meios para observar "a utilidade" procurada pelo ator e "os limites" percebidos pelo ator, e sem se questionar sobre a inadequação entre o indivíduo teórico de seu modelo e os indivíduos sociais tomados em seu pertencimento mutável a entidades coletivas. O melhor antídoto para esse etnocentrismo da racionalidade econômica (quer dizer, da racionalidade epistêmica dos economistas) consiste em tentar reconstituir os raciocínios nativos, ou racionalidades práticas ${ }^{3}$, empregues nos comportamentos observados. Em particular, para retomar uma sugestão de Max Weber (2000) sobre a gênese de uma "personalidade unificada", mostrarei que os raciocínios nativos diferem de uma cena social para outra, e utilizarei as práticas de mensuração, anotação, ordenamento e contabilidade como índices da existência de cenas sociais distintas. Com efeito, contra as hipóteses da unidade das personalidades individuais (unicidade e estabilidade das preferências de um indivíduo dado ex ante, da parte da teoria econômica; permanência do habitus individual de um indivíduo construído por uma socialização primária todo-poderosa, da parte da teoria sociológica), adotaremos a hipótese que os indivíduos dispõem de uma pluralidade de sistemas de referência ${ }^{4}$ e agem em várias cenas sociais em que as regras de comportamento, os objetivos procurados, os limites percebidos, as racionalidades práticas, são distintos. A atenção às práticas de medida e de contabilidade permitirá compreender como os indivíduos obtêm êxito em articular essas diferentes cenas sociais.

Em um primeiro momento, mostrarei que a diversidade das unidades de medida, evidenciada ao longo de uma pesquisa sobre horticultura amadora, revela as diferenças de estatuto entre vários tipos de objeto, por um lado, e entre vários tipos de atividade, por outro, em função do enquadramento, jurídico e material, das práticas domésticas. Em um segundo momento, analisarei o papel do recurso à escrita nas transações monetárias não comerciais, comparando-as com as transações comerciais sem anotação. Enfim, recordarei que existe uma racionalidade prática de administração do orçamento nas classes populares, apesar da ausência de práticas explícitas de medida e de contabilidade. Minha proposta aqui é menos dar conta de uma pesquisa unificada e acabada do que oferecer, a partir de alguns exemplos etnográficos, pistas de reflexão sobre os raciocínios nativos, suas ferramentas comuns e sua diversidade ${ }^{5}$. 


\section{O que revelam as práticas de medida}

O ponto de partida de minhas questões sobre as unidades nativas de medida reside em uma pesquisa por questionário postal, conduzida em 1990, junto a um milhar de horticultores amadores espalhados por toda a França (sobretudo no Norte e no Oeste). O objetivo dessa investigação era recolher dados precisos sobre as práticas da horticultura para compreender a que racionalidade prática elas obedeciam ${ }^{6}$. A hipótese de um cálculo econômico efetuado pelo horticultor e referido aos custos efetivos e aos custos evitados levou-me a colocar questões a respeito da superfície das hortas cultivadas, das despesas permitidas em consumos intermediários, da avaliação da quantidade das colheitas e dos "lucros" in natura (produtos alimentares, flores cortadas...) obtidos pelos horticultores. A idéia era calcular, a partir desses dados, a "rentabilidade econômica" dessas práticas, para saber que horticultores plantavam para economizar dinheiro e que horticultores plantavam por um outro motivo.

Pesquisas semelhantes, com o mesmo objetivo, já haviam sido conduzidas: as monografias da escola de Le Play esforçaram-se, a partir de 1850, para medir a economia doméstica nas famílias "operárias" e, nesse quadro, em avaliar os bens produzidos pelas famílias; as pesquisas regulares do Institut Nacional de la Statistique et des Études Économiques (INSEE) sobre consumo alimentar conferem, desde 1950, um lugar ao autoconsumo; uma pesquisa pontual do INSEE, em 1988, sobre a produção doméstica consagra uma parte à horticultura; múltiplas pesquisas, mais ou menos rigorosas, conduzidas por promotores da horticultura amadora, buscam avaliar, em porcentagem de autoconsumo ou em equivalente monetário, os "lucros" in natura obtidos pela horta.

\section{O cálculo "científico" dos lucros e dos custos não monetários}

A seriedade e a importância das avaliações monetárias dos produtos de horticultura variam ao longo do século XX. No começo deste, as diferentes leis de proteção social dos indigentes, que deixam a tarefa às prefeituras e a seus gabinetes de caridade, reservam um lugar importante aos recursos não monetários dos pobres. Alguns gabinetes lhes concedem uma horta em lugar de uma subvenção, pois levam em conta os produtos dessa horta na avaliação de seus recursos. Após um longo eclipse, interrompido somente pelas duas guerras mundiais, durante as quais a questão das vantagens in natura proporcionadas pelas hortas encontra uma reatualização, é no momento do estabelecimento do Revenue Minimum d'Insertion 
$(\mathrm{RMI})^{*}$, nos anos 90, que essas avaliações encontram o peso que haviam perdido ao longo dos Trinta Gloriosos**. Com efeito, tratou-se, por um breve momento, de desfalcar do montante do RMI o equivalente monetário dos produtos da horta.

Além de abandonarem a "questão social" e as políticas sociais encarregadas de responder a esta (ver Castel 1995), as discussões em torno dessas avaliações monetárias fazem sentido em relação à lenta desaparição das "vantagens in natura" oferecidas, como complemento do salário monetário, a algumas profissões ou a algumas categorias da população (albergue e alimentação das domésticas, alojamento de porteiros, diversos alojamentos funcionais, diárias nas empresas ou na função pública).

Uma grande inovação nos cálculos dos ganhos e despesas não monetários efetuados no plano individual pelos economistas ou pelos juristas (em caso de conflito trabalhista ou familiar, por exemplo), foi a tomada em conta do tempo de trabalho não remunerado. Na França, essa inovação ocorreu, de início, na agricultura, quando em 1939 o direito de família reconhece, no momento da sucessão, que a criança que trabalha sob a exploração de seus pais sem outra contrapartida senão "casa e comida" tem direito a uma compensação em relação a seus irmãos e irmãs que se tornaram assalariados. Esta compensação, paga sob a forma de uma parte mais significativa na herança, é contabilizada como "manque a gagner" [ausência de ganho] em contraste com um salário, que os juristas decidem nomear "salário diferido", cujo montante é fixado sob a forma de indenização (Barthez 1982; Bessière 2001). O fenômeno segue confinado à agricultura até os anos 90 (Monteillet-Geoffroy 2001), quando o princípio do "salário diferido" é estendido, sob condições, da agricultura ao artesanato, ao comércio e às profissões liberais e aos filhos de casais dos profissionais concernidos.

Paralelamente a essa tímida profissionalização do trabalho exercido no quadro de empresas familiares, a partir dos anos 80, a questão do valor monetário do tempo de trabalho não profissional é colocada por alguns economistas a propósito do trabalho doméstico feminino (ver o artigo pioneiro de Chadeau e Fouquet 1981, ou ainda Chabaud-Rychter, FougeyrollasSchwebel e Sonthonnaux 1985). Nesse interregno, a questão do valor monetário do tempo exterior ao do trabalho aparece no campo da economia

* Estabelecimento de uma renda mínima para os sem renda, associado à preferência de inclusão no mercado de trabalho. [N.T.]

* * Período de crescimento econômico entre o fim da Segunda Grande Guerra e 1975. [N.T.] 
teórica sob a forma do "custo de oportunidade" — termo utilizado pelos economistas para avaliar o custo individual do tempo passado em atividades sem remuneração (lazer, sono etc.), ou ausência de ganhos.

Todas essas avaliações têm em comum não levar em consideração os raciocínios nativos, quando, na verdade, as vantagens em espécie (moças que trabalham sem salário, alojamentos) são tão claramente percebidas pelos interessados quanto se fossem contratos de trabalho escritos, enquanto as avaliações dos ganhos e dos custos não monetários repousam sobre cálculos efetuados por cientistas (economistas ou sociólogos) a partir de questionários. A pesquisa que realizei em 1990 junto a 1.000 horticultores amadores inscrevia-se nessa lógica. Mas, contrariamente às anteriormente citadas, tratava-se de uma pesquisa amplamente artesanal, em que as formulações restringiam pouco as respostas dos pesquisados. Em particular, eu não fixara por antecipação as unidades de medida das diversas quantidades inquiridas, quer se tratasse da superfície das terras ou dos produtos recolhidos. Ao mesmo tempo, essa enquete permitiu iluminar a diversidade dos sistemas de medida utilizados pelos respondentes: diversidade segundo o meio social, mas sobretudo diversidade no próprio interior de cada resposta, segundo o objeto medido. Se a variabilidade entre as respostas individuais podia corresponder a diferenças nas competências escolares dos indivíduos interrogados, a variabilidade presente no interior de cada resposta individual abria novas perspectivas.

\section{Diversidade das unidades de medida nativas}

Primeiro resultado importante: a superfície do terreno disponível (propriedade ou locação) é conhecida com grande precisão em mais de $80 \%$ das respostas. O sistema de medição utilizado é o are e o hectare (mais para os pesquisados rurais ou de origem rural), ou então o metro quadrado (para a maioria). As respostas são dadas em metros quadrados inteiros e os pesquisados, na ocasião, consultaram seus títulos de propriedade ou seus contratos. Ao contrário, a superfície cultivée en legumes ["cultivada com vegetais"] é dada na proporção do terreno descrito na primeira pergunta. Quando o cientista, para efetuar seus cálculos (de produtividade, por exemplo), converte desatentamente em metros quadrados essa porção plantada da horta, ele desconsidera o fato importante que esta operação extremamente simples não é efetuada pelo horticultor. Por que os pesquisados não efetuam tal cálculo? É porque as duas questões (superfície do terreno disponível e superfície da horta cultivada) remetem a dois universos diferentes. No primeiro caso, a superfície do terreno remete ao universo jurídi- 
co da propriedade e da locação; no segundo, a superfície da horta remete ao universo doméstico do cultivo, externo a toda obrigação profissional. Ter-se-ia podido refinar a análise, levando em conta as restrições residenciais (regulamentos de co-propriedade, por exemplo, nos loteamentos) ou associativas (regulamentos das hortas familiares), que podem pesar sobre o cultivo dos terrenos. Essas restrições são geralmente formuladas proporcionalmente ao terreno disponível.

Duas observações etnográficas vêm precisar este primeiro resultado. Se a unidade de medida utilizada no universo jurídico está inscrita nos títulos de propriedade a que se referem os pesquisados, as modalidades práticas de medida dos terrenos cultivados não podem ser descobertas sem se recorrer à observação direta. Quando de uma pesquisa efetuada nos anos 90 em Nantes ${ }^{7}$, em uma zona de hortas de operários sem enquadramento associativo nem jurídico, a etnógrafa observou a partilha dos terrenos disponíveis (espécie de terreno baldio) pelos primeiros horticultores instalados. Um deles, imigrado de origem portuguesa, delimitava a parcela que desejava cultivar utilizando seus olhos e seus passos. Media a grandes passos, calculando instantaneamente a superfície de que tinha necessidade para alimentar seus quatro filhos com batatas durante um ano. Cálculo impreciso, é claro, ou antes de uma precisão suficiente para o uso futuro, mas que supõe uma série de conhecimentos práticos não acessíveis ao recém-chegado: número de pés de batatas a plantar em uma superfície dada, quilos de batatas colhidas por pé plantado, quilos de batatas consumidas por ano pela família...

No universo do campesinato e em outro contexto econômico, uma tese etnográfica efetuada no Nordeste do Brasil, nos anos 90 (Abreu 1993), descreve em detalhe os efeitos dessas competências práticas, detidas pelos camponeses, sobre o fraco desempenho escolar de seus filhos. Os pequenos plantadores cultivam a cana-de-açúcar e necessitam avaliar a superfície de suas diferentes parcelas para pagar os trabalhadores e para vender sua produção às usinas. Porque as parcelas não têm forma regular, eles efetuam essa avaliação recorrendo, ao mesmo tempo, ao cálculo mental (para as somas) e ao cálculo escrito (para as multiplicações), utilizando os arredondamentos e cortando as formas irregulares em quadrados e em triângulos. Esta técnica complexa, mas eficaz para calcular uma superfície, concorre, no momento da escolarização de seus filhos, com os ensinamentos de cálculo e de geometria e é, ao menos em parte, responsável pelo mau desempenho escolar destes últimos. 


\section{Coexistência e articulação de diferentes sistemas de medição e de cálculo}

Nos dois casos nos encontramos em presença de operações cognitivas adaptadas às necessidades práticas, e as técnicas de medição ou de cálculo não devem nada ao sistema formal sobre o qual repousa a competência dos técnicos: intervenção de agrimensores, existência de um cadastro, passagem para o sistema métrico. Ao contrário, o sistema formal reassume toda a sua importância no universo da agricultura profissional, quando, por exemplo, alguns subsídios são concedidos em função do modo de cultura das parcelas - é preciso, portanto, medir com precisão. Não se trata de opor um universo jurídico e formal, que seria exterior às práticas, a um universo espontâneo, informal e incorporado que ocuparia todo o espaço das práticas. Muito pelo contrário, as pesquisas evocadas aqui mostram a coexistência e a articulação de vários quadros de referência distintos. Os títulos de propriedade (mas em outros casos, os subsídios ou os regulamentos residenciais) levam os horticultores ao uso de uma medida oficial que se apóia no sistema métrico utilizado por profissionais da mensuração (os agrimensores, por exemplo). O quadro profissional e comercial (pagar trabalhadores por hectares, vender uma produção) obriga os camponeses do Nordeste a um cálculo prático cuja precisão está adaptada a seu uso. O quadro doméstico (cultivar batatas suficientes para o consumo familiar anual) leva o português de Nantes a um outro cálculo prático, que não passa pela intermediação de uma medida da superfície, mas que avalia diretamente a produção final da parcela considerada.

A pluralidade de sistemas de medida e de cálculo adaptados a usos diferentes não significa que eles sejam incompatíveis nem que a conversão seja impossível. Ao contrário, observa-se, quando a situação impõe, uma articulação entre os sistemas ou o recurso a sistemas alternativos. Do mesmo modo que o bilingüismo não leva à confusão mental nem verbal ${ }^{8}$, a coexistência de várias unidades de contagem é possível, como o mostra, na França, a manutenção dos antigos francos nas classes populares quando se trata de montantes excepcionais ou, nas classes dirigentes, da capacidade de manejar os "quilofrancos" * paralelamente aos francos correntes da vida cotidiana. Último exemplo, a adaptação rápida dos profissionais a uma nova moeda, o euro, em janeiro de 2002, permite apreender a incorporação rotineira das operações mentais. O breve momento de hesitação

* $\quad$ Valor correspondente a mil francos. [N.T.] 
dos caixas no momento da passagem do franco ao euro mostra a coexistência de dois modos de dar o troco. A modalidade "intelectual" do cálculo, a das calculadoras e das caixas registradoras, opera uma subtração: soma recebida "menos" soma devida. A própria operadora opera a subtração ou fixa sua atenção no resultado desta subtração, indicado pela caixa. A modalidade "manual" do cálculo, muito mais rápida, uma vez apreendida, opera uma soma: soma devida "mais" moedas devolvidas até o montante da nota dada pelo cliente (que, efetuando a mesma operação mental, "facilitou o troco" para facilitar a soma). A caixa conta então as moedas com as mãos, sem passar pelo montante total da soma que deve devolver. Durante alguns dias, a chegada das moedas com valores não familiares desestabilizou totalmente essa modalidade manual do cálculo, que repousa na identificação automática das moedas ordenadas nos compartimentos do caixa, e que evita ao operador todo esforço mental. As caixas foram então obrigadas a contar "ao contrário" de seus hábitos, se remeter à modalidade intelectual do cálculo e a passar pela subtração para devolver uma soma intelectualmente conhecida, mas não percebida automaticamente. O retorno à modalidade manual demorou, ao menos para os profissionais, apenas alguns dias.

\section{Medidas domésticas: utensílios de estocagem, percepção do tempo}

Segundo resultado da pesquisa junto aos horticultores amadores: as quantidades de legumes estocados (em conservas ou congelados) são conhecidas graças aos recipientes utilizados para a estocagem. Sobre a questão das quantidades colhidas dos produtos, para a qual eu omitira a precisão de uma unidade de medida (quilos ou litros), as respostas são dadas em "vidros de conservas", por um lado, em "partes do congelador", por outro. Na ocasião, alguns horticultores precisaram o volume dos vidros utilizados (vidros de um litro, de meio litro), ou o volume do congelador (dado assim em litros). Uma vez mais, a operação de conversão é de simples efetuação: a metade de um congelador de tantos litros; tantos vidros de um litro e tantos vidros de meio litro. Mas, ainda aí, é significativo que ela não seja efetuada espontaneamente pelos pesquisados. Obtém-se assim uma idéia da "medida prática" efetuada pelos horticultores ou pelas cozinheiras, inteiramente dependente dos utensílios. Ferramentas cognitivas e utensílios materiais estão fortemente ligados. Não há necessidade de passar pelo sistema oficial para saber "quanto" se pode fazer de conservas ou de congelamentos. É mesmo provável que o lugar da estocagem disponível condicione inteiramente não apenas a percepção das quantida- 
des estocadas, mas a própria prática da estocagem: horticultores e cozinheiras conservam tantos legumes quanto são capazes de armazenar nas prateleiras ou no congelador; o resto, doam ou consomem imediatamente.

Nessas condições, pode-se perguntar o que significam as medidas efetuadas pelos pesquisadores em suas pesquisas sobre a produção doméstica. Porque estas medidas são efetuadas em quilogramas, unidade métrica divisível, a elas faltam as unidades práticas que revelam a lógica da produção doméstica. Bastaria conhecer o "sistema de estocagem" utilizado por cada horticultor para compreender sua lógica de produção. A adaptação da prática cotidiana aos objetos que o enquadram é, sem dúvida, suscetível a modificações: mudança de congelador em função das modificações de tamanho da família, por exemplo, decisões de cultivo da horta em função do espaço de estocagem. Mas os objetos e os espaços são dotados de uma forte permanência, que explica o essencial das atividades da "rotina" cotidiana. Efeitos de limite e coerência do sistema prático no qual a jardinagem tem lugar: a medida "métrica", contínua e divisível à vontade, não restitui esses dados fundamentais da prática. Assim, um dos horticultores inquiridos me devolve seu questionário riscado com um traço irado: sua esposa morreu, ele planta somente flores. Como um cálculo objetivo de rentabilidade poderia dar conta de uma decisão desta natureza, quando tudo é revolucionado de um só golpe?

Terceiro e último resultado: alguns indivíduos se recusaram simplesmente a responder à questão sobre o tempo gasto na horta. Desta vez, previ a unidade de medida do tempo: perguntei por um número de horas por semana na boa estação e na má estação. A maior parte dos horticultores dobrou-se de bom grado à consigna, comentando às vezes sua resposta: "isso depende" - depende do clima, das necessidades da horta e das disponibilidades do horticultor. Mas algumas respostas foram radicais: "eu não conto". A horta, ao contrário do tempo profissional, escapa ao relógio. Como então aceitar avaliar, mesmo grosseiramente, o que justamente deve todo o seu preço a essa ausência de avaliação? Essa recusa de "contar seu tempo" não acarreta simplesmente um incômodo técnico para hipotéticos cálculos de rentabilidade, como uma suspeita da legitimidade do empreendimento. Ela inscreve de modo extremamente nítido a medida horária do tempo no campo do trabalho assalariado, e particularmente do trabalho submetido à marcação de ponto. Não se deve esquecer aqui os belos desenvolvimentos de E. P. Thompson (1979) sobre o tempo industrial, nem os de P. Bourdieu sobre o tempo dos camponeses e o dos proletários (Bourdieu e Sayad 1964; Bourdieu et alii 1964). Os trabalhos mais recentes de M. Bruegel mostram a dimensão ostentatória do recurso ao 
relógio nos meios burgueses da Nova Inglaterra no século XIX. Aqui é a dimensão liberadora da ausência de medida do tempo que é avançada, de modo aliás clássico nas culturas populares do século XX.

Além dessas recusas, de resto minoritárias, pode-se reter uma questão importante que as pesquisas Emprego do Tempo do INSEE e as diferentes pesquisas sobre o tempo de trabalho evidenciavam igualmente. Uma vez que a norma do trabalho assalariado se impõe progressivamente nos empregos não assalariados (por exemplo, o tempo de trabalho na agricultura [Barthez 1986]), o uso não profissional do tempo é suscetível de dois tipos diferentes de cálculo: um cálculo por subtração (o tempo que resta para tal atividade), um cálculo por soma (o tempo que é necessário para tal atividade). As diferenças entre estes dois modos de avaliação podem ser consideráveis, como mostram as pesquisas sobre o tempo de trabalho doméstico das mulheres, caso tenham ou não um emprego. As primeiras subtraem seu tempo de trabalho e seu tempo de sono das 24 horas do dia para avaliar seu tempo doméstico: o que resta. As segundas somam os tempos que dedicam às suas diversas atividades. Uma vez mais, é a articulação entre os diferentes universos que está em jogo: articulação entre o universo profissional e o universo doméstico, para as mulheres assalariadas; articulação entre vários universos domésticos, para as outras (ajuda na escolaridade das crianças, arrumação, cozinha, tempo das atividades não profissionais fora do domicílio).

É claro, o recurso à objetividade aparente da medição (tempo do relógio, comprimento da régua, peso da balança, superfície do geômetra) permite efetuar cálculos liberados dos limites dos raciocínios nativos. Mas, de que vale uma medida "científica" para explicar comportamentos se ela não é utilizada, ou seja, percebida, pelas pessoas concernidas? O anacronismo faz imediatamente o historiador sorrir. Para o observador das sociedades contemporâneas, menos sensível talvez à dimensão etnocêntrica de suas operações, é bom lembrar que, no universo em que o relógio, a balança e o cadastro são onipresentes, seu uso não se impõe uniformemente em todos os domínios da prática nem, como veremos em seguida, em todos os universos de relações sociais, em todas as "cenas sociais". Além disso, o recurso às técnicas de medida se faz acompanhar, por vezes, de conflitos em torno da legitimidade da medida ou da pertinência das ferramentas ${ }^{9}$. Esquecê-lo, é ceder a uma visão angélica das relações sociais e das relações entre ciência (trata-se das ciências sociais) e sociedade. 


\section{O que revela a anotação das transações}

A pesquisa sobre os horticultores amadores mostra que a utilização de uma unidade de medição (metros quadrados ou porção da horta; quilogramas, potes ou porção do congelador; horas de relógio ou tempo necessário para tal atividade) depende do contexto de referência da prática (título de propriedade ou produção doméstica, balanço do comerciante ou ateliê da cozinheira, máquina de ponto profissional ou horas ao sol). Sustentado por objetos materiais em que são cristalizadas relações sociais ${ }^{10}$, esse contexto de referência remete a uma "cena social" na qual fazem sentido as práticas e as interações.

Para precisar o conceito de cena social, examinarei agora as transações, comerciais ou domésticas, vagamente separadas do fluxo das interações cotidianas por instituições oficiais como a Bolsa, os bancos, o direito comercial e de negócios, o fisco, ou pelos múltiplos profissionais que enquadram, sem serem forçosamente visíveis, as atividades econômicas legais. Essas transações marginais, sob todos os pontos de vista, devem sua significação somente a objetos e a gestos imediatamente observáveis ao longo da interação. O etnógrafo pode então descobrir a olho nu o que separa duas interações sucessivas entre os mesmos parceiros, e mesmo compreender como a mesma interação pode assumir simultaneamente várias significações distintas para um ou para outro dos parceiros (risco do malentendido) ou para os dois (coexistência de várias interpretações). Esses objetos e esses gestos determinam o significado da interação, fixam o sentido do acontecimento em curso. Por isso, eu os considero como os "quadros rituais" dessa interação ou desse acontecimento. Com efeito, sabe-se desde Bateson e Austin que o ritual, assim como a língua, tem uma dupla dimensão, performativa e significativa, e que as regras rituais, como as regras de um jogo, separam não a ação boa da ação má (o que fazem as regras morais), mas a ação válida, graças à qual o jogo pode continuar, da ação "fora de jogo", que não tem sentido e muito simplesmente não pode ter lugar, que interrompe o jogo e desqualifica o jogador. Para retomar o exemplo do naven estudado por Bateson (1971[1936]) ${ }^{11}$, cada um dos participantes sabe que, adotando tal comportamento, se faz o naven e que, fora dos comportamentos ritualmente prescritos (o que não diz nada sobre o valor moral), o ator deixa de fazer o naven para fazer outra coisa. Do mesmo modo, ao longo das interações que acabamos de examinar, alguns gestos e alguns objetos significam, sem dúvida alguma, que o que está em via de acontecer é um contrato comercial, uma aposta ou um presente, um gesto afetuoso ou uma prestação de serviço. Ao contrário, algumas intera- 
ções são suscetíveis de várias interpretações: se essa pluralidade de interpretações é percebida por cada um dos atores, diremos que a interação se situa na interseção de várias cenas sociais; se os parceiros não partilham o conjunto dessas significações, diremos que há mal-entendido e risco de conflito ulterior.

Começaremos a examinar as operações comerciais que resultam, sem nenhuma dúvida, da cena comercial, mas que têm lugar à margem das instituições oficiais: elas revelam a importância dos rituais que isolam a transação de seu contexto imediato e permitem-lhe inscrever-se em uma série de transações análogas. Sugeriremos que, comumente, esse papel é desempenhado pela anotação das transações comerciais nas listas ou nos registros: ela tem uma dimensão ritual tanto quanto uma dimensão cognitiva. Além do fato de permitir fazer contas, adicionar perdas e ganhos por exemplo (dimensão cognitiva), uma tal inscrição fixa o sentido da transação sem contestação possível (dimensão significativa) porque ela reagrupa todas as transações de mesma natureza e as isola de seu contexto espaço-temporal (dimensão performativa). Depois observamos transações que ensejam sua inscrição ainda que elas não se efetuem em um quadro oficial. Sugeriremos então que, também aí, a anotação das transações, porque as reagrupa e as isola de seu contexto, "inscreve-as" em uma cena social separada, o que permite aos parceiros conduzir suas relações em diferentes cenas.

\section{Os quadros rituais da transação comercial}

Estamos tão habituados ao enquadramento jurídico e institucional das transações comerciais que esquecemos tudo o que um contrato comercial ou um ato de compra e venda mobiliza como atividade administrativa e profissional, sem contar a complexidade dos meios de pagamentos ordinários. É preciso ter tentado, como simples particular, ultrapassar a cadeia de intermediações comerciais para adquirir um bem diretamente junto à unidade de produção para ter idéia da complexidade das cadeias comerciais invisíveis que separam o produtor industrial do consumidor final $^{12}$. Alguns meios profissionais funcionam, contudo, sem essa cadeia de interações entre comprador e vendedor. Sua observação etnográfica revela então, sob uma forma anedótica ou pitoresca, a existência de uma forma ritual obrigatória para selar uma transação. O interesse dessas pesquisas etnográficas reside no estranhamento que elas nos proporcionam: longe das garantias jurídicas oferecidas pelos contratos e pelo direito comercial, que se fazem acompanhar de provas escritas e de assinaturas, elas nos le- 
vam ao universo em que a palavra dada e o pertencimento ao grupo são suficientes.

A pesquisa de Alain Tarrius (1995) no bairro de Belsunce, em Marselha, mostra a existência de um meio de negócios argelino muito ativo nos anos 90 . Um personagem dotado de grande autoridade consuetudinária, fora de qualquer jurisdição legal, serve ali de testemunha para todas as transações comerciais importantes. Esta garantia da palavra dada se cerca de um cerimonial específico; ela permite evitar todo recurso à escrita. Sua autoridade está intimamente ligada à existência de um meio de interconhecimento muito extenso onde a informação circula rapidamente. Toda falta ao contrato feito oralmente diante desse tabelião consuetudinário é sancionada muito simplesmente pela exclusão do meio. Tal sistema não impede a circulação de somas consideráveis e uma atividade comercial complexa, ligada notadamente à importação/exportação entre o Magrebe e a França, que envolve profissionais e não-particulares.

A pesquisa de Hervé Sciardet no Mercado das Pulgas de Saint-Ouen trata também de um meio profissional à margem das instituições, mas que repousa menos no interconhecimento pessoal do que na capacidade de decifrar os índices do estatuto das pessoas, garantindo o estatuto dos objetos. Assim, segundo a hora do dia, os lugares da transação e a atitude ou o comportamento das pessoas, o especialista em objetos de segunda mão saberá se está negociando com um marchand e com um objeto de valor, com um marginal e com um objeto de origem incerta ou com um antiquário e com um objeto falsificado. Tal sistema de signos continua opaco para o leigo, mas oferece oportunidades de embuste e de lucro aos profissionais. As transações ali obedecem a formas mínimas de ritualização, invisíveis para o observador desavisado, mas suficientes como signos de reconhecimento entre profissionais. É o quadro da interação que dá sua significação à transação, quadro ao qual o comportamento dos parceiros se adapta. Assim, a transação "comercial", segundo a terminologia nativa (poderíamos traduzir o termo, que designa a posição mais alta na hierarquia dos compradores, pelo de "profissional"), acontece ao amanhecer, vasculhando-se nos porta-malas dos carros vindos durante a noite de um centro provincial de antiguidades, e consiste na troca de um objeto acabado de sair de sua embalagem original por uma certa quantidade de cheques ostensivamente retirados de um talão. A ritualização da transação consiste aqui na unidade de tempo (amanhecer) e do lugar (a calçada) e no caráter espetacular dos objetos: o objeto vendido conserva o traço de seu universo de origem; o talão de cheques permite medir de um golpe de vista a importância, indissociavelmente financeira e social, de quem o manipula. 
Trata-se mesmo, em todos os sentidos da palavra, de uma encenação, quer dizer, da inscrição da interação em um cenário que lhe dá sentido ${ }^{13}$.

\section{Anotação das dívidas e dos créditos}

A análise etnográfica dos rituais, a seu modo espetaculares, efetuados sem nenhum recurso à notação escrita nem ao sistema administrativo e jurídico que enquadra habitualmente as transações comerciais, mostra como, na ausência desses suportes, uma transação inscreve-se em uma série aos olhos de seus diferentes protagonistas. Tal análise revela ao mesmo tempo o papel desempenhado pelos suportes habituais nessa definição da transação comercial. Abordaremos agora as transações não mais entre profissionais (como nos casos estudados por A. Tarrius e H. Sciardet) mas entre particulares. O quadro oficial faz sempre falta e o risco de mal-entendidos é muito mais presente do que nas transações entre profissionais. Nos perguntamos como os particulares engajados nas transações obtêm êxito em fixar sua interpretação, mesmo quando são tomados em numerosas interações de vários tipos: a interseção das cenas sociais é aqui o caso mais freqüente. Avançaremos a hipótese de que a escrita desempenha então um papel fundamental para fixar o sentido das transações: ela isola as transações escrituradas do curso ordinário das coisas e as constitui em séries autônomas.

Começarei por relatar uma observação isolada. Quando de uma pesquisa conduzida, em torno de 1990, junto a famílias "inadimplentes", rotuladas como tais pelos organismos de crédito e pelos bancos e designadas como alvos de uma política de ajuda específica, iniciamos com um colega uma entrevista clássica à mesa da sala e diante do gravador. Havíamos abordado com o casal entrevistado toda a gama de seus diversos créditos, na moradia e no consumo, a administração de seu orçamento, suas trajetórias profissionais e residenciais. Depois, não sei como, a jovem mulher nos conduziu ao quarto de dormir para falar-nos de um empréstimo suplementar, desconhecido dos bancos, junto a um de seus parentes. O empréstimo estava escrito a giz no interior da porta do armário. Cada reembolso parcial dava lugar a um traço e à anotação da dívida restante.

Nenhuma dúvida de que se poderia descobrir no universo das relações familiares anotações desse gênero em grande número. Trata-se, neste caso, de transações duplamente específicas: elas ocorrem entre particulares e não são objeto de nenhum contrato, não assumem nenhuma forma oficial. São, portanto, distintas do fluxo das interações ordinárias que ligam um credor e um devedor quando estes são também parentes. O cará- 
ter não oficial da transação explica a forma não habitual da anotação: no caso evocado, a dívida é inscrita a giz, em uma porta interior do armário, um pouco como o crédito inscrito sobre ardósia entre os pequenos comerciantes. É a necessidade de isolar a transação, de constituir em seqüência significativa o empréstimo e a série de seus reembolsos parciais, que explica a própria existência de tais anotações. A operação cognitiva (uma soma de dinheiro de onde se subtrai os reembolsos efetuados gradativamente) torna-se possível pela escrita em sua dimensão performativa: reconhecimento de dívida, quitação. É possível que o traço não corresponda a um pagamento efetivo, mas à decisão, por um motivo ou outro, de anular a dívida. A anotação fixa a significação dessas transferências de dinheiro que, sem ela, poderiam também ser presentes, adiantamentos da herança, pagamentos de serviços, reembolsos de taxas etc. ${ }^{14}$.

\section{Compras em grupo, redes de relações}

Uma vez assinalada a existência de tais anotações e descoberta sua significação, é fácil identificar práticas análogas. O exame das anotações domésticas contemporâneas constitui um campo de pesquisas ainda pouco explorado ${ }^{15}$, marcado pela abundância e heterogeneidade das práticas, desde a manutenção de uma agenda, de um repertório de endereços, até os múltiplos cadernos consagrados aos lazeres ou aos acontecimentos familiares (Fine, Labro e Lorquin 1993), ao arquivamento de correspondência e à manutenção de contas ou relações com os administradores. Tomaremos o exemplo das anotações referentes a compras em grupo na qual a transação monetária é um pretexto para o estabelecimento de uma rede de relações. Trata-se de uma tabela fotocopiada indicando encomendas de ovos (nas colunas os nomes dos "clientes", nas linhas a semana em questão, nas casas a quantidade de ovos encomendados e pagos) que foi descoberta por acaso na casa do senhor e senhora Bricq, um casal de aposentados pertencente à elite local dos operários qualificados da fábrica Vallourec, em Montbard. A esposa é de origem local e tem vários primos agricultores; o marido foi trabalhar na fábrica no momento em que esta recrutava largamente no exterior seus operários qualificados, nos anos 60. A trajetória social do casal é marcada por tentativas frustradas de sair da classe operária para uma profissão independente (posto de gasolina, restaurante), por uma vontade de acesso à propriedade e pelo investimento educativo em seus filhos (um tornou-se advogado comercial, o outro sommelier e depois professor de ensino técnico). A proximidade social com o meio dos pequenos empresários (restauradores, agricultores...) é marcada 
por uma forte valorização das competências comerciais, que encontra uma realização parcial na organização de redes de compras de produtos alimentares ${ }^{16}$ : vinhos prestigiosos comprados diretamente dos produtores, descobertos pelo filho sommelier que agrupa as encomendas de mais de uma dezena de casas; carne comprada do produtor, também para diversas famílias. Nesse amálgama de compras em grupo (a senhora Bricq também fez parte de um grupo Tupperware), uma prática é suficientemente rotineira para dar lugar ao estabelecimento de um quadro mensal: é a compra de ovos de um grande produtor local que abastece os supermercados da região. São ovos muito grandes para serem escoados no comércio; o produtor vende-os diretamente a particulares. A senhora Bricq organiza as compras semanais de uma dezena de vizinhos e conhecidos graças ao quadro onde ela anota, semanalmente, semana após semana, a quantidade encomendada por cada um.

Trata-se, então, de verdadeiras transações comerciais nas quais a senhora Bricq serve simplesmente de intermediária desinteressada. A tabela tem um uso técnico evidente: ela permite evitar os erros de encomenda e rotinizar a prática. Argumentaria igualmente que ela serve de quadro semicomercial que permite isolar o ato de comprar ovos da série de relações múltiplas que unem a senhora Bricq a cada um de seus parceiros: a existência da tabela delimita uma cena social particular, de limites estreitos, na qual cada transação "ovos contra pagamento monetário" ganha sentido. Ela resume a posição de intermediária gratuita da senhora Bricq, que efetua uma operação duplamente benevolente: presta serviços a seus vizinhos, para quem proporciona ovos "muito grandes" por uma quantia módica, assim como ao produtor, a quem oferece uma possibilidade informal de escoamento de produtos não padronizados. Para ela, a série dessas transações constitui um pretexto para manter um feixe de boas relações e para utilizar competências comerciais sem perspectiva profissional. Ela camufla, portanto, um presente (dom de tempo e de organização) que lhe permite afirmar suas qualidades sob a aparência de uma transação comercial (compra e venda) e só isola esta cena social microscópica para melhor combiná-la com a das relações de vizinhança. Os dois parceiros da transação comercial tornam-se assim seus obrigados. Nenhuma ambigüidade subsiste quanto aos pagamentos em dinheiro (trata-se mesmo do pagamento dos ovos) nem quanto à transferência dos ovos (eles não são um presente). A ausência de ambigüidade permite que a sobreposição de cenas sociais (todos esses "clientes" são "amigos") jogue positivamente com o estatuto da senhora Bricq, pondo-a em posição aceitável de intermediária competente e devotada. 


\section{Uma caderneta de horas de trabalho doméstico}

Poderíamos encontrar muitos outros exemplos dessas práticas de compras em grupo, freqüentemente organizadas gratuitamente no universo profissional. Todas as vezes, as anotações das transações têm uma dupla função: técnica de organização, de natureza cognitiva, permitem fazer rapidamente as contas e as encomendas; técnica de separação, que isola a transação de seu contexto interpessoal, têm uma dimensão ritual em que conferem sua significação ao ato transcrito e impedem que o fluxo contínuo de interações pessoais seja afetado pela venda de um produto contra o pagamento monetário. Tomarei um último exemplo para pôr em evidência a dupla função, cognitiva e ritual, de tais anotações e, sobretudo, o modo como essas práticas domésticas permitem superpor sem mistura dois tipos de relações diferentes, quer dizer, articular uma relação pessoal e uma transação comercial.

Trata-se de uma caderneta na qual a senhora Février anota as horas de trabalho doméstico feito por ela em uma residência secundária. A senhora Février é casada com um operário especializado da Vallourec, empregado também nos anos 60, de origem parisiense. Ela é filha de agricultores, antes horticultores em Paris, que se mudaram para assumir uma grande fazenda no Châtillonnais. Alguns de seus irmãos são empresários (agricultores ou transportadores), alguns de seus cunhados são funcionários. Na geração de seus filhos, encontramos um tipo de elite operária: técnico em calefação, secretária, funcionário do Service National des Chemins de Fer (SNCF), garagista, operário de fábrica, vendedora. A senhora Février nunca trabalhou na fábrica, tendo se dedicado à educação de seus quatro filhos e trabalhado de diarista. Ela trabalhou vinte anos na residência secundária de um professor parisiense e depois na da única filha dele. Foi paga com salário mensal durante um período e, após a morte de sua primeira patroa, passou a ser paga por hora de trabalho na casa ou no jardim. Foi ela quem estabeleceu o sistema de caderneta. Na ausência de qualquer controle (ela tem as chaves e os parisienses freqüentemente não estão), é esta caderneta que regula a relação de trabalho: ela anota suas horas mês após mês, com a indicação do dia em questão e os gastos ou os acontecimentos que dizem respeito à casa. Ela é paga todos os meses e o pagamento é igualmente anotado na caderneta.

Contrariamente às aparências, não se trata apenas de uma técnica de organização. Como nos casos precedentes, talvez ainda mais, a caderneta de contas isola a relação de trabalho de seu contexto, retendo apenas os elementos ligados ao pagamento (salário ou reembolso), além de permi- 
tir à patroa e à diarista manter, simultaneamente, uma relação de trabalho, transparente graças à caderneta, e uma relação amigável, sustentada por trocas de presentes, de convites recíprocos, passeios ou saídas em comum, cujos diversos elementos nunca são mencionados na caderneta. Considerada pela patroa simplesmente como um instrumento cômodo de administração da casa, a caderneta é objeto de uma ligação sentimental da parte da empregada para quem ela representa as horas trabalhadas (investidas de um certo orgulho profissional) e uma fonte de ganhos não negligenciáveis dado o orçamento familiar muito baixo (uma pré-aposentadoria de "operário especializado").

Espero ter mostrado, nesses poucos exemplos, a dupla função, cognitiva e ritual, da anotação de transações. Partindo da existência nos universos profissionais de rituais não escritos que efetuam a transação (dimensão performativa) e lhe dão sentido (dimensão significativa), mostrei em seguida, nos universos domésticos, como a inscrição de várias transações permite constituir séries, isolar a transação de seu contexto interpessoal e, finalmente, articular sem confusão vários tipos de relações diferentes: relação comercial, relação de trabalho, relação de crédito com as relações pessoais, de parentesco, de vizinhança, de amizade. Vimos o papel das anotações nos raciocínios nativos - elas classificam as transações em categorias tão estanques quanto possível — , onde as unidades de medida servem apenas de índices para demarcar diversas categorias nativas de percepção dos objetos e das atividades e as práticas de anotar transações mostram a operação de classificação em ato.

\section{Um ascetismo prático sem anotação nem medida}

Retornemos, brevemente, para finalizar com os comportamentos que parecem corresponder, à primeira vista, ao modelo proposto pela microeconomia do consumidor na versão mais simples (maximizar sua utilidade sob forte limitação orçamentária), mesmo quando as técnicas de administração doméstica utilizadas não recorram nem à escrita nem à contabilidade. O "consumidor racional" pode recorrer a técnicas de autocontrole que não devem nada à operação de uma competência escritural ou contável. O "cálculo econômico" pode não ser um "cálculo" explícito mas, muito simplesmente, um modo de vida que repousa sobre formas de ascetismo incorporadas: as racionalidades práticas não se oferecem sempre à observação sob a forma de raciocínios explícitos, listas de anotações ou atividades medidas, mas podem permanecer automáticas ou inconscientes. 
Tomarei dois exemplos nas classes populares francesas, antes de sua desestabilização nos anos 8017. Trata-se de famílias estáveis, em que o marido é operário qualificado ou baixo funcionário e a esposa faz apenas trabalhos complementares, que educaram os filhos dispondo de ganhos reduzidos porém regulares. Esta forte limitação orçamentária levou-os a desenvolver práticas eficazes de autocontrole, tanto mais eficazes quanto mais interiorizadas, automatizadas: não há necessidade de pensar nelas.

Os dois exemplos formam um contraponto às análises propostas por Bernard Lahire (1993) sobre os usos populares da escrita prática. A partir de uma pesquisa com operários homens e serventes mulheres de escolas maternais, ele descobriu que as mulheres utilizam mais freqüentemente a escrita que os homens e interpretou uma série de práticas heterogêneas (listas de compras, controle de contas, formas de diário íntimo) como instrumentos de autocontrole. Os dois casos que evoquei acima assinalam a existência de formas eficazes de autocontrole sem nenhum recurso à escrita. Dissociar ascetismo orçamentário e escrita prática é uma operação ainda mais clara desde que Jean-Pierre Albert (1993) mostrou a que ponto os usos mais intensivos da escrita prática podem ser separados de todo cuidado orçamentário e remeter a uma definição de si mais expressiva que eficaz ${ }^{18}$. Ele encontrou pessoas cujas casas eram repletas de etiquetas, bilhetes, enfeites com palavras, cujo papel era exprimir a personalidade do morador (ativo, ordenado, metódico, sistemático) mais do que tornar sua atividade mais eficaz. Encontramos em muitos outros casos uma encenação da atividade que desloca o interesse, do resultado da ação, para a própria ação ${ }^{19}$.

\section{Um ascetismo incorporado}

Voltemos ao caso da senhora Bricq, evocado acima por ocasião da tabela de venda de ovos a seus vizinhos. Vimos então que ela dominava as técnicas da escrita prática para atingir um objetivo complexo: imitando a competência comercial, prestava serviços a seus vizinhos e a seu fornecedor sem, contudo, dar a eles outro presente que a sua atividade organizadora, por intermédio da qual ela afirmava suas qualidades. As características sociais de sua família explicam, aliás, que ela tenha desenvolvido formas de ascetismo incorporado na relação com os objetos. Ela adquiriu comportamentos fortemente automatizados que evitam o recurso ao cálculo numérico, aplicando uma forma muito eficaz de cálculo econômico (no sentido de minimização dos gastos). Assim, ela nunca dá descarga no banheiro sem pedir a seu marido para ir depois dela para usar apenas uma quantidade de água para os dois. Tal comportamento tornou-se com- 
pletamente rotineiro, a ponto de ela continuar a tê-lo fora de sua casa, quando ela não paga a água: observei-o de passagem em um abrigo rural alugado por amigos onde a água economizada favoreceria o proprietário que ela não conhecia e que não tinha consciência disso. Pode-se considerar, desse ponto de vista, que a senhora Bricq é um exemplo de personalidade unificada no sentido de Max Weber, cujos princípios, adquiridos ao longo de sua biografia, não são recolocados em causa nem interrogados em cada ocasião. Entretanto, esses princípios, próximos da "filosofia do sovina" descrita por Weber a propósito de Benjamim Franklin, podem ter conseqüências paradoxais: a família perdeu muito dinheiro após várias tentativas de saída da classe operária.

\section{Uma técnica popular de administração orçamentária: os "envelopes"}

Lembrarei, para terminar, a existência de uma técnica de administração orçamentária muito disseminada nos meios populares, na França, até os anos 70. No exemplo que nos interessa, essa técnica era acompanhada por um salário mensal característico da função pública, em um período em que os operários eram em grande parte pagos por semana. Ela só se explica em um universo em que os cheques não eram de uso corrente ${ }^{20}$, ou seja, antes de 1973, data em que os salários dos operários começaram a ser pagos mensalmente, o que levou a uma explosão de aberturas de contas bancárias.

Tomarei o exemplo de um casal residente em Crépand (Côte d'Or) ${ }^{21}$ entre 1945 e 1978, data em que os conheci. O marido era agente do SNCF, sua mulher nunca exerceu nenhuma atividade profissional e eles criaram quatro filhos. Eles me contaram em 1978 como conseguiram "se virar", apesar de seu salário extremamente baixo. Durante todo o período em que seus filhos eram pequenos, eles distribuíam, assim que recebiam, o pagamento mensal do marido, única fonte de ganhos, nos vários envelopes destinados um ao leite para as crianças, outro ao padeiro, o terceiro para o pagamento da eletricidade etc., ou seja, às prioridades de despesa. Eles nunca tiravam dinheiro de um envelope para cobrir um gasto ao qual o envelope não estava destinado. Tratava-se, então, de uma previsão orçamentária rudimentar, de pequena escala, mas muito eficaz. O casal observado sempre satisfez as necessidades que considerava prioritárias. Com esse sistema, o dinheiro não afetado, ou a entrada extra de dinheiro, pôde ser utilizado sem medo para uma "loucura" : prática popular bem estudada por Richard Hoggart (1970[1957]) e que escandaliza os observadores, sempre prontos a considerar que os pobres são irracionais. 
Essa prática dos envelopes, de grande difusão ${ }^{22}$, é um exemplo notável de técnica material que cumpre um papel cognitivo. Ela não utiliza a escrita, a contabilidade, a listagem, nem o cálculo numérico. É uma simples técnica de ordenamento que, reservando somas de dinheiro, efetuando uma classificação em categorias de gastos futuros, permite saber sempre onde estão os gastos e as receitas, permite "racionalizar" os gastos, controlando-os mais precisamente. Há mesmo uma racionalidade prática do comportamento de consumo, sem que esta racionalidade passe pelo uso da escrita nem do cálculo numérico.

Esse ascetismo orçamentário, incorporado ou objetivado em dispositivos materiais como os envelopes, está fortemente ligado à posição social particular desses casais que fazem parte da elite popular honrada e relativamente pobre, bem estudada nos trabalhos recentes de história social (para uma síntese, ver Cartier 2000). Poderíamos nos interrogar sobre as práticas atuais de administração do orçamento nas classes populares desestabilizadas, mas que conservam ganhos regulares pagos mensalmente (alocações diversas) ${ }^{23}$. Quisemos mostrar simplesmente o interesse e a complexidade de um estudo sério sobre as práticas econômicas das famílias, que leva em conta raciocínios nativos e não se contenta em imputar motivações e crenças às pessoas cujos comportamentos são observados, sem tampouco considerar que basta perguntar para que elas entreguem ao pesquisador a verdade de suas práticas ${ }^{24}$. Tal estudo não poderia fazer economia da reflexão sobre as relações entre práticas de autocontrole e limites exteriores. Não se trata de acreditar na espontaneidade das práticas de consumo e de administração orçamentária. Trata-se antes de uma adaptação, de um modo de composição com limitações de natureza diversa para organizar um espaço de vida viável. Em particular, seria preciso interessar-se pelos diversos momentos da "socialização econômica", desde a escola até os primeiros contatos com as instituições bancárias, fiscais, e as proposições comerciais, para observar o triplo sistema de normas que pesam sobre os "consumidores": normas familiares em sua diversidade, normas ascéticas sustentadas pelas instituições encarregadas de reprimir os delitos de não-pagamento, incitações ao consumo sustentadas pelo marketing e, mais recentemente, pelos apelos políticos a um civismo do consumo.

Lembremos um último ensinamento desses exemplos. A racionalidade das práticas econômicas tem ainda uma dimensão normativa. Ela depende do que os diferentes observadores julgam razoável. Se alguns economistas confundem racionalidade epistêmica e eficácia prática, acreditando que é razoável tentar ser o mais forte, outros observadores, filan- 
tropos, assistentes sociais, agentes administrativos em contato com os pobres e mais ou menos encarregados de moralizar seus comportamentos, estigmatizando a irracionalidade dos consumidores pobres, conferem a eles um julgamento moral. Uma verdadeira sociologia das práticas econômicas dos indivíduos, quer dizer, de seus comportamentos de consumo, de trabalho e de troca, deveria preocupar-se em penetrar o sistema de gestão e as limitações que pesam sobre as pessoas. É preciso abandonar a concepção desmaterializada e abstrata do cálculo ou da racionalidade e restituir a materialidade das categorias nativas de classificação (o envelope, a fatura, a moeda ${ }^{25}$ ), e mesmo sua incorporação (em manias ascéticas ou, ao contrário, nos comportamentos ostentatórios). Teríamos então uma oportunidade de compreender os raciocínios implícitos que passam pelas coisas e pelos corpos.

\section{Conclusão}

Espero ter contribuído para dar algumas pistas para a análise dos raciocínios nativos que operam nas práticas cotidianas, quer esses raciocínios sejam explícitos, quer estejam inscritos nas coisas, nos corpos, nos traços escritos deixados por interações ritualizadas. Espero também ter contribuído para esclarecer os termos do debate com a teoria microeconômica do consumidor. Um primeiro ponto diz respeito à firme distinção entre racionalidade epistêmica (a modelização "científica", efetuada pelos economistas, dos comportamentos nativos) e racionalidades práticas, quer dizer, raciocínios nativos ou "modos de pensar", sejam elas implícitas ou inscritas materialmente. Do lado da racionalidade epistêmica, a formalização econômica padrão dos comportamentos individuais está fora de questão. Pode-se procurar um outro modo de explicar os comportamentos individuais partindo de premissas diferentes. Para o interacionismo metodológico, por exemplo, teoria bem adaptada à observação etnográfica, o indivíduo não é um dado ex ante, Atena com elmo saída do cérebro de Júpiter, mas uma lenta e instável conseqüência de múltiplos processos de socialização, que podem ser contraditórios nas diferentes cenas sociais por vezes estanques, por vezes imbricadas. Pode-se, por outro lado, tentar melhorar a apreensão do real oferecida pelo instrumental matemático da microeconomia. Esta é a tarefa dos economistas teóricos quando procuram propor novas formalizações; é também tarefa dos econometristas quando meditam sobre os testes empíricos que permitem identificar, por um lado, os limites efetivamente percebidos pelos atores cujo comportamento modelizam e, 
por outro, os objetivos efetivamente perseguidos por estes: o que se impõe a economistas teóricos e econometristas é preencher essa concha vazia que é a utilidade ou o bem-estar. É mesmo possível ajudá-los, portanto, a descrever corretamente os diferentes sistemas de valores e reduzir a heterogeneidade dos comportamentos individuais, restituindo a dimensão coletiva desses sistemas de valores ${ }^{26}$. É talvez possível também se interrogar com eles sobre a unidade de análise dos comportamentos. Com efeito, depois de se ter contentado por muito tempo com figuras abstratas - o casal, a firma - a microeconomia abre hoje suas caixas-pretas para levar em consideração uma unidade menor: o indivíduo fisiológico (Browning et alii 1994). Ela não abandonou demasiado rápido a possibilidade de uma decisão coletiva? Sem negar que o indivíduo fisiológico nasce, morre e, no intervalo, sofre, sente e reflete, ele também se identifica com um coletivo e seus interesses individuais não se podem dissociar dos interesses de seu grupo de pertença. O interacionismo etnográfico sugere que o indivíduo fisiológico se situa no cruzamento de vários coletivos e de vários universos de socialização. A teoria microeconômica não poderia apreender essas hipóteses para ajudar a etnografia a perguntar-se sob que condições Ego age como um Eu confrontado com outro Eu, sob que condições se trata de algo como um Nós? Assim, as hipóteses relativas à dinâmica própria da interação ${ }^{27}$ não poderiam ser modeladas pela teoria dos jogos?

Enfim, deixando de lado essas questões de modelização, espero ter sugerido que o estudo dos raciocínios nativos pode vir a constituir para as ciências sociais descritivas um campo de pesquisas de grande amplitude. Apenas esboçamos aqui três pistas que poderiam ser seguidas por pesquisas sistemáticas. Primeira: para um mesmo indivíduo, o raciocínio difere segundo a cena social em que se situa a interação. Há cenas sociais em que a avaliação monetária dos objetos é proibida, absurda, sem pertinência; há outras em que ela é permanente ${ }^{28}$. Algumas situações impõem não contar, outras levam imediatamente ao cálculo, por vezes retroativo ${ }^{29}$. Melhor ainda: uma única relação interpessoal subdivide-se em várias seqüências, cada uma suscetível de um raciocínio diferente. Só a ruptura ou a morte, dando fim de um só golpe a todas as seqüências, autoriza ou impõe um tipo de contabilidade final, um "balanço" no duplo sentido do termo ${ }^{30}$.

Segunda pista: a significação de uma transação é fixada graças aos quadros rituais, gestos e dispositivos materiais. São estes quadros que permitem a observação direta. As transações deixam também, muito freqüentemente, traços escritos cuja forma, os detalhes, as omissões, podem ser sistematicamente estudados. Não se trata de considerar que esses traços restituem uma ação anterior ou diferente de sua inscrição, mas, antes, que 
a anotação faz a transação, que ela fixa sua significação. Abre-se aqui o estudo das modalidades das transações como fenômeno ao mesmo tempo cultural, social e econômico: a questão desemboca em uma etnografia das práticas comerciais, dos contratos entre profissionais, dos jogos entre os espaços da transação oficial, que põe entre parênteses as relações pessoais, e o espaço de suas multiplicidades (Garcia 1986; Pradelle 1996; Hassoun 2000).

Terceira pista: a manutenção de um orçamento doméstico opera competências prognósticas que não passam forçosamente por um cálculo explícito dos gastos e das receitas. Restituir os raciocínios nativos supõe, portanto, pesquisas detalhadas sobre a percepção dos limites e sobre as práticas de autocontrole em diferentes classes sociais, para mostrar como se agenciam limites de ganhos, limites estatutários e espaços de liberdade em função dos ritmos da vida cotidiana.

A matematização das ciências sociais, apesar dos excessos ligados a uma confiança exagerada nesse instrumental, apesar da desconfiança igualmente excessiva que ela pôde suscitar, poderia mesmo abrir uma nova era na compreensão das práticas sociais, na condição de efetuar um esforço considerável de tradução dos conceitos e das questões em jogo nas diferentes disciplinas em questão; na condição de sistematizar as aquisições da sociologia e da antropologia; e na condição, também, de evitar falsos debates ${ }^{31}$ e economizar energia para cooperações mais proveitosas.

Florence Weber é professora de sociologia e etnologia na École Normale Supérieure e dirige o Laboratoire des Sciences Sociales (ENS-EHESS). É autora de diversos artigos sobre culturas populares na França, parentesco e trocas em economias não mercantis, e sobre a história da etnografia francesa. Publicou Le Travail à-Côté. Étude d'Ethnographie Ouvrière (1989, reed. 2001), L'Honneur des Jardiniers. Les Potagers dans la France du 20e Siècle (1998), Le Guide de l'Enquête de Terrain (com Stéphane Baud, 1997), e uma antologia comentada de textos de Max Weber (2001). 


\section{Notas}

* Este artigo faz parte de uma coletânea organizada por Natacha Coquery, François Menant e Florence Weber, Écrire, Compter, Mesurer. Le Calcul Économique à l'Épreuve de l'Histoire et de l'Ethnographie (Paris: Editions Rue d'Ulm) a ser publicada em 2003. Agradeço aos editores a autorização a esta publicação prévia em português.

1 Cf. por exemplo os dois artigos clássicos de Durkheim e Mauss (1903) e Hubert e Mauss (1906). O primeiro mostra que "o procedimento lógico que está na base das classificações científicas" (em particular as de "gênero" animal e de "classe" de objetos) não encontra sua origem nem no mundo sensível, nem na nossa consciência, mas na sociedade: “As próprias expressões das quais nos servimos [...] autorizam a presumir que todas essas noções lógicas são de origem extralógica. Dizemos que as espécies de um mesmo gênero sustentam relações de parentesco; chamamos algumas classes de família; a própria palavra gênero não designaria primitivamente um grupo familiar?" (Mauss 1971:166). Ou ainda: "Longe de ser fundamentado admitir como evidente que os homens classificam tudo naturalmente, por um tipo de necessidade interna de seu entendimento individual, deve-se, ao contrário, perguntar o que pôde levá-los a dispor suas idéias sob essa forma e onde puderam encontrar o plano dessa notável disposição" (Mauss 1971:167). O segundo constitui uma introdução aos estudos sobre o sacrifício e a magia e desemboca no exame das concepções de tempo e espaço: "Há modos de pensar em comum tanto quanto há modos de agir em comum" (Mauss 1968:36). O acento é posto aqui sobre a linguagem e os hábitos de pensamento, freqüentemente inconscientes: “Constantemente presentes na linguagem, sem que elas sejam necessariamente explícitas, [as categorias] existem comumente antes sob a forma de hábitos diretores da consciência, eles mesmos inconscientes" (Mauss 1968:8). Esses textos inspiraram toda a antropologia britânica e francesa após Lévi-Strauss, toda a sociologia lingüística, e uma grande parte da sociologia americana e francesa. Apesar de uma ambigüidade sobre a natureza desse inconsciente, precipitadamente assimilado ao inconsciente freudiano, e do individualismo débil que espreita parte das ciências sociais contemporâneas, esse programa, em um momento em que as ciências cognitivas e a economia experimental retomam a questão, guarda toda sua atualidade. Esperemos que elas não tenham esquecido esta primeira formulação explicativa.

2 Apesar das conotações coloniais deste termo, continuarei a utilizá-lo, pois tem o mérito de dissociar a posição do observador da dos indivíduos observados, ou "nativos". Ele não assinala a superioridade do primeiro sobre os segundos, mas sua exterioridade, seja esta dada (quando o observador, etnógrafo ou historiador, não pertence ao universo estudado) ou trabalhosamente adquirida (quando o observador estuda o seu próprio universo social). A distância entre observador e observados não exclui a reflexividade da análise, muito ao contrário. Ela permite estudar por contraste o universo nativo ao qual pertence o observador. É essa mesma comparação, explícita ou implícita, que serve de motor às questões e às análises do cientista. 
3 Retomo a distinção fundamental entre essas duas racionalidades de Granger (1995).

4 Entre os pesquisadores que avançaram recentemente uma idéia análoga de pluralidade dos sistemas de referência, que exige a análise dos comportamentos individuais segundo a cena (ou "circuito") na qual são observados, ver, em particular, Lahire (1998) e Zelizer (2000). Nada de revolucionário, aliás, nessas proposições, que se contentam em utilizar, em um outro contexto científico e conferindolhe uma outra grandeza teórica, a noção bem estabelecida de "papéis" desempenhados por um indivíduo em diferentes "cenas sociais". O conceito de "cena social" é plenamente desenvolvido em F. Weber (2001).

5 Este artigo é uma versão profundamente modificada de minha comunicação Les Conditions Cognitives des Pratiques Économiques ao colóquio Écrire, Compter, Mesurer, organizado pelo Département d'Histoire da École Normale Supérieure e pelo Laboratoire de Sciences Sociales (ENS-EHESS), 21-22 de março 2001, em Paris.

6 Mais precisamente, desejei confrontar duas explicações da horticultura amadora: seu uso como "contradesvantagem" [contre-handicap] por fração das classes populares que tinham acesso fora do mercado a produtos alimentares "de luxo" (frescos e de boa qualidade); seu uso como "afirmação de si", acentuando a atividade mais que seu resultado. A apresentação completa da pesquisa e de suas questões encontra-se em F. Weber (1998).

7 Para um relato dessa experiência, ver Pasquier e Petitot (2001).

8 Pode-se aqui estender a questão do bilingüismo verdadeiro à coexistência de vários registros de linguagem, utilizáveis em cenas sociais diferentes. Assim, um operário encontrado em 1983 em Montbard reconhece ter hesitado entre empregar comigo a "língua dos companheiros" ou a "língua dos engenheiros".

9 Ver, sobre exemplos muito particulares, Chatury (1997). É também essa a questão abordada por Jérôme Gautier (no prelo) e Alain Desrosières (no prelo).

10 Tomo emprestado o conceito de "cristalização" da tradição durkheimiana.

11 Para uma releitura recente, ver Houseman e Severi (1994).

12 Na seqüência de uma quebra do estoque em uma grande loja parisiense, na véspera do Natal, e para não privar meus filhos de seu presente (um jogo de totó), negociei com o vendedor (a quem encomendei e paguei pela mercadoria) de ir procurar eu mesma seu fornecedor, a alguns quilômetros do meu lugar de férias. Passei o dia inteiro com um sentimento intenso de transgressão quando, finalmente, consegui. 
13 O etnógrafo é particularmente sensível a esse aspecto das interações comerciais (cf. Pradelle 1996). A despeito das críticas de que tal abordagem pode ser objeto, ela tem o mérito de perguntar "quem" encena, "quem" isola as transações e lhes confere um sentido unívoco. Por vezes, a resposta excede as possibilidades da observação direta (seria necessário levar em conta o trabalho da administração fiscal, dos bancos etc.). Outras vezes, a resposta é acessível à pesquisa direta. Para um exemplo particularmente feliz, ver Garcia (1986).

$14 \mathrm{O}$ exame dos autos de um processo de filiação permitiu-me compreender a ambigüidade das transferências monetárias no parentesco e a necessidade de fixar seu significado. Uma mulher, F., deixou seu marido para viver sozinha com seu filho; seu amante, A., dava-lhe em cheque um tipo de pensão mensal regular, de um montante fixo. F. considerava essa quantia uma ajuda para o pagamento de seu aluguel. Ao fim de alguns meses, F. retornou ao domicílio conjugal e A. tentou um processo de paternidade legítima para fazer-se reconhecer como o pai natural da criança. A pensão desempenhou então um papel importante: A. apresentou-a como a prova de que ele tinha participado das despesas da criança; o advogado de $\mathrm{F}$. tentou apresentá-la como o reembolso de uma dívida anterior, contratada na época de suas relações profissionais (A. e F. eram colegas de trabalho). O juiz aceitou a interpretação de A. Houve uma série de outros depósitos entre A. e F. (A. utilizou seus extratos bancários como prova dos depósitos), mas não havia elementos que permitissem esclarecer seu significado interpessoal: no momento desses depósitos, seria necessário considerar A. e F. como colegas, amigos, amantes, parentes?

15 Os trabalhos pioneiros nesse domínio são os de Lahire (1993) e Albert (1993).

16 Para a valorização desses produtos na cultura operária local, ver F. Weber (2001).

${ }^{17}$ Sobre a periodização da história social das classes populares no fim do século XX, ver Cartier (2000).

${ }_{18}$ Muitas cadernetas dedicadas a uma atividade de lazer valorizada, reagrupando fotografias, artigos de jornal, relatos, remetem a uma lógica de afirmação de si em uma cena social específica, como por exemplo as "cadernetas de caça" dos caçadores populares.

${ }^{19}$ Chamei alhures essas duas modalidades da valorização dos objetos e das atividades, "estética da contemplação" (interesse pelo resultado) e "estática da produção" (interesse pela própria atividade).

${ }^{20}$ Lembremos que as pessoas sob interdição bancária voltam hoje à situação de antes de 1973 (administração do orçamento em numerário) em um mundo onde a ausência de cheques constitui um estigma pesado.

${ }^{21}$ Estudei este caso no contexto do povoado, em F. Weber (1978/79). 
22 Seria preciso estender a pesquisa aos manuais de economia doméstica para verificar se essa prática foi difundida pela escola, o que parece provável.

${ }^{23}$ Alguns elementos presentes nas pesquisas recentes nos permitem sugerir o papel dos Correios como instituição principal de enquadramento para os orçamentos desses casais mais pobres, assim como a importância renovada de uma administração que repousa no manuseio do numerário e não nas contas mais abstratas implicadas pelos meios de pagamento mais "modernos". Para observações recentes no guichet, ver Siblot (1999).

${ }^{24}$ Para uma crítica análoga das imputações de motivações e de crenças em vista dos comportamentos observados, mas desta vez no domínio da ciência política e não da ciência econômica, ver Mariot (2001).

25 "Dar a moeda", colecionar moedas: os comportamentos econômicos das classes populares estão ligados freqüentemente, mais do que em algumas frações das classes superiores, à materialidade do dinheiro. Para uma primeira série de pesquisas sobre a questão, ver o número especial de Terrain, "Les Usages de l'Argent", no 23, outubro de 1994. As transformações dos meios de pagamento têm efeitos sobre as práticas que seria interessante estudar.

26 Trata-se do ethos de classe, como em Bourdieu? Do ethos de corpo, quer dizer, de grupo de status, como em Weber? De ethos partilhado por toda uma sociedade, como para os teóricos culturalistas?

${ }^{27}$ Em particular, o conceito de cismogênese de Bateson e sua extensão à análise configuracionista por Elias (ver F. Weber 2001a).

${ }^{28}$ Para dois exemplos de avaliação monetária permanente em um contexto não comercial, ver a contribuição de Alban Bensa (no prelo) e Sarrasin (1994); para uma discussão sobre a legitimidade do cálculo econômico, ver as contribuições de Alain Desrosières (no prelo), de Jérôme Gautier (no prelo) e de Agnès Gramain (no prelo).

${ }^{29}$ É, por exemplo, o caso no momento das rupturas e das mortes. No momento de um divórcio, tem-se a impressão de ver revelada a verdade das relações tecidas durante o casamento. É falso: essas relações são suscetíveis de várias interpretações: antes do divórcio não se contava da mesma maneira...

${ }^{30} \mathrm{O}$ caso das profissões que envolvem serviços pessoais e das relações de parentesco oferece notáveis oportunidades para colocar tais questões (ver, p. ex., Cartier 2000).

31 Assim como a questão da irracionalidade dos comportamentos observados. Do mesmo modo como, antes, os "primitivos" foram percebidos como seres irracionais simplesmente porque os observadores não os compreendiam, os comportamentos nativos hoje só aparecem como "irracionais" porque eles continuam ininteligí- 
veis para nós. Quando a fronteira entre racional e irracional designa a frente pioneira da ciência (aquilo de que ela poderia dar conta, aquilo que ainda lhe escapa), quer dizer, da racionalidade epistêmica, os estudiosos têm a tendência de projetar essa fronteira sobre seu objeto e de julgar alguns comportamentos "irracionais" quando eles não compreendem a que racionalidade prática eles obedecem.

\section{Referências bibliográficas}

ABREU, Guida de. 1993. The Relationship between Home and School Mathematics in a Farming Community in Rural Brazil. Tese de Doutorado, Cambridge.

ALBERT, Jean-Pierre. 1993. “Écritures Domestiques". In: D. Fabre (dir.), Écritures Ordinaires. Paris: OL/BPI. pp. 37-94.

BARTHEZ, Alice. 1982. Famille, Travail e Agriculture. Paris: Economica.

_ . 1986. "Du Labeur Paysan au Métier d'Agriculteur: L'Elaboration Statistique en Agriculture". Cahiers d'Economie et Sociologie Rurales, 3:45-72.

BATESON, Gregory. 1971[1936]. La Cérémonie do Naven. Paris: Minuit.

BENSA, Alban. (no prelo). "Compter les Dons: Échanges Non Marchands et Pratiques Comptables en NouvelleCalédonie Kanak Contemporaine". In: N. Coquery, F. Menant e F. Weber (orgs.), Écrire, Compter, Mesurer. Le Calcul Économique à l'Épreuve de l'Histoire et de l'Ethnographie. Paris: Éditions Rue d'Ulm.

BESSIÈRE, Céline. 2001. Sexe, Cognac et Capitaux. Mémoire du DEA de Sciences Sociales, ENS-EHESS.

BOURDIEU, Pierre et alii. 1964. Travail et Travailleurs en Algerie. Paris: Mouton.
BOURDIEU, Pierre e SAYAD, Adbelmalek. 1964. Le Déracinement. Paris: Minuit.

BROWNING, Martin, BOURGUIGNON, François, CHIAPPORI, Pierre-André e LECHÊNE, Valérie. 1994. "Income and Outcomes: A Structural Model of Intrahousehold Allocation". Journal of Political Economy, 1029(6): 1067-1096.

CARTIER, Marie. 2000. "Le Calendrier du Facteur. Les Significations Sociales d'un Échange Anodin". Genèses, 41: 63-84.

CASTEL, Robert. 1995. Les Métamorphoses de la Question Sociale: Une Chronique du Salariat. Paris: Fayard.

CHABAUD-RYCHTER, Danielle, FOUGEYROLLAS-SCHWEBEL, Dominique e SONTHONNAUX, Françoise. 1985. Espaces et Temps du Travail Domestique. Paris: Libraire des Méridiens.

CHADEAU, Anne e FOUQUET, Anne. 1981. "Peut-on Mesurer le Travail Domestique?". Economie et Statistique, 136:29-41

CHATURY, Giordana. 1997. Folie, Mariage e Mort. Pratiques Chrétiennes de la Folie en Europe Occidentale. Paris: Seuil.

COQUERY, Natacha, MENANT, François e WEBER, Florence (orgs.). (no prelo). Écrire, Compter, Mesurer. Le Calcul 
Économique à l'Épreuve de l'Histoire et de l'Ethnographie. Paris: Éditions Rue d'Ulm.

DESROSIÈRES, Alain. (no prelo). "Peut-on tout Mesurer? Les Deux Sens, Technique et Social, du Verbe Pouvoir". In: N. Coquery, F. Menant e F. Weber (orgs.), Écrire, Compter, Mesurer. Le Calcul Économique à l'Épreuve de l'Histoire et de l'Ethnographie. Paris: Éditions Rue d'Ulm.

FINE, Agnès, LABRO, Stéphanie e LORQUIN, Claire-Emmanuelle. 1993. "Lettres de Naissance". In: D. Fabre (dir.), Écritures Ordinaires. Paris: OL/ BPI. pp. 117-147.

GARCIA, Marie-France. 1986. "La Construction Social d'un Marché Parfait: Le Marché au Cadran de Fontaineen-Sologne". Actes de la Recherche, 65.

GAUTIER, Jérôme. (no prelo). “De l'Invention du Chômage à sa Déconstruction". In: N. Coquery, F. Menant e F. Weber (orgs.) Écrire, Compter, Mesurer. Le Calcul Économique à l'Épreuve de l'Histoire et de l'Ethnographie. Paris: Éditions Rue d'Ulm.

GRAMAIN, Agnès. (no prelo). "Les Enjeux Scientifiques et Politiques de la Modélisation Micro-Économique". In: N. Coquery, F. Menant e F. Weber (orgs.) Écrire, Compter, Mesurer. Le Calcul Économique à l'Épreuve de l'Histoire et de l'Ethnographie. Paris: Éditions Rue d'Ulm.

GRANGER, Gilles-Gaston. 1995. "Les Trois Aspects de la Rationalité Économique". In: L-A. Gerard-Varet e J.-C. Passeron (orgs.), Le Modèle et l'Enquête. Les Usages du Principe de Rationalité dans les Sciences Sociales. Paris: Ed. EHESS. pp. 561575.

HASSOUN, Jean-Pierre. 2000. "Trois Interactions Hétérodoxes sur les Marchés à la Criée du MATIF. Racional- ité Local, Racionalité Global". Politix, 13(52):99-119.

HOGGART, Richard. 1970 [1957]. La Culture du Pauvre. Paris: Minuit.

HOUSEMAN, Michael e SEVERI, Carlo. 1994. Naven ou le Donner à Ver. Essai d'Interpretation de l'Action Rituelle. Paris: Ed. CNRS/Ed. MSH.

LAHIRE, Bernard. 1993. La Raison des plus Flaibes. Rapport au Travail, Écriture Domestiques et Lectures en Millieux Populaires. Lille: Press Universitaires de Lille.

. 1998. L'Homme Pluriel: Les Ressorts de l'Action. Paris: Nathan.

MARIOT, Nicolas. 2001. "Les Formes Élémentaires de l'Effervescence Collective, ou l'État d'Esprit Prêté aux Foules". Revue Française de Science Politique, 51(5):707-738.

MAUSS, Marcel. 1968. Oeuvres, tomo 1. Paris: Minuit.

.1971. Essais de Sociologie. Paris: Seuil (Col. Point).

MONTEILLET-GEOFFROY, Mélanie. (2001), Les Conditions de l'Enrichissement sans Cause dans les Relations de Famille. Thése de Droit, Université d'Orléans, Doctorat et Notariat, 4, Imp. La Mouette.

PASQUIER, Elisabeth e PETITOT, JeanYves. 2001. Cultiver son Jardin. Chroniques des Jardins de la Fournillère, 1992-2000. Paris: L'Harmattan.

PRADELLE, Michèle de la. 1996. Les Vendredis de Carpentras. Faire son Marché, en Provence ou Ailleurs. Paris: Fayard.

SARRASIN, Philipp. 1994. "Une Coutume Barbare. Les Fonctions Significantes de l'Argent dans une Société Bourgeoise vers 1900". Genèses, 15: 84-102.

SIBLOT, Yasmine. 1999. Le Service Public en Milleu Populaire: Stigmatisation et Intégration. Une Enquête dans un Poste de Banlieue Parisien. Mé- 
moire du DEA de Sciences Sociales, ENS-EHESS.

TARRIUS, Alain. 1995. Arabes de France dans l'Économie Mondial Souterraine. La Tour d'Aigues: Ed. de l'Aube. THOMPSON, Edward P. 1979. "Temps, Travail et Capitalisme". Libre, 5.

WEBER, F. 1978/79. Conflits et Devenirs de Familles Rurales dans un Village de Bourgogne du Nord. Mémoire de Maîtrise d'Ethnologie, Paris V. . 1998. L'Honneur des Jardiniers. Paris: Belin. .2001. "Settings, Interactions and Things. A Plea for Multi-Integrative Ethnography". Ethnography, 2(4): 475-499.

. 2001a. Le Travail à-Coté. Paris: Ed. EHESS.

WEBER, Max. 2000. L'Ethique Protestante et l'Esprit du Capitalisme. Paris: Flammarion.

ZELIZER, Viviana. 2000. "How and Why Do we Care about Circuits". Newsletter of the Economics Sociology Section of the American Sociological Association. 


\section{Resumo}

Este artigo parte da hipótese da existência de uma pluralidade de cenas sociais em que os indivíduos interagem e as ações individuais adquirem sentido. A cada cena social correspondem racionalidades práticas diferentes. $\mathrm{O}$ exame das práticas de mensuração e contabilidade permite distinguir essas cenas e compreender como se articulam entre si. Para mostrar a diversidade de raciocínios nativos, utiliza-se primeiro a diversidade das unidades de medida usadas por horticultores amadores. Em seguida, examinam-se os quadros rituais de diversas transações e mostra-se que o consumidor racional - no sentido da teoria utilitarista - pode não recorrer a nenhum cálculo explícito, pois o ethos ascético encontra-se inscrito nas rotinas corporais. Para concluir, o artigo convida a um estudo sistemático da socialização econômica e propõe três pistas para a pesquisa: a descrição da diversidade de cenas sociais, a análise dos quadros rituais das transações, e o estudo das percepções dos constrangimentos e das práticas de autocontrole nas diversas classes sociais. O artigo sugere que, dessa forma, se poderiam definir domínios de validade para as formalizações matemáticas das condutas humanas elaboradas pelos economistas.

Palavras-chave Racionalidade, Economia, Cálculo, Cena Social

\section{Abstract}

This article proceeds from the hypothesis that a plurality of social scenes exist in which individuals interact and individual actions acquire meaning. Each social scene corresponds to different practical rationalities. Examining the practices involved in measuring and counting allows us to distinguish these scenes and comprehend how they are mutually interconnected. As a demonstration of the diversity of native reasoning, the article first turns to the wide variety of units of measurement used by amateur horticulturists. Next, it examines the ritual settings of various transactions and shows that the rational consumer - in the sense expounded by utilitarian theory - need not rely on any explicit calculation, since the ascetic ethos can be found inscribed in body routines. In conclusion, the article calls for a systematic study of economic socialization and outlines three leads for such research: description of the diversity of social scenes, analysis of the ritual settings of transactions, and study of the perceptions of constraints and the practices of self-control among the various social classes. The author suggests such an approach may enable us to define domains of validity for the mathematical formalizations of human behaviours developed by economists.

Key words Rationality, Economy, Calculation, Social Scene 